\title{
Preliminary Report on Monosodium Titanate Adsorption Kinetics
}

by

D. T. Hobbs

Westinghouse Savannah River Company

Savannah River Site

Aiken, South Carolina 29808

M. G. Bronikowski

W. R. Wilmarth

DOE Contract No. DE-AC09-96SR18500

This paper was prepared in connection with work done under the above contract number with the U. S.

Department of Energy. By acceptance of this paper, the publisher and/or recipient acknowledges the U. S. Government's right to retain a nonexclusive, royalty-free license in and to any copyright covering this paper, along with the right to reproduce and to authorize others to reproduce all or part of the copyrighted paper. 


\section{DISCLAIMER}

This report was prepared as an account of work sponsored by an agency of the United States Government. Neither the United States Government nor any agency thereof, nor any of their employees, makes any warranty, express or implied, or assumes any legal liability or responsibility for the accuracy, completeness, or usefulness of any information, apparatus, product, or process disclosed, or represents that its use would not infringe privately owned rights. Reference herein to any specific commercial product, process, or service by trade name, trademark, manufacturer, or otherwise does not necessarily constitute or imply its endorsement, recommendation, or favoring by the United States Government or any agency thereof. The views and opinions of authors expressed herein do not necessarily state or reflect those of the United States Government or any agency thereof.

This report has been reproduced directly from the best available copy.

Available to DOE and DOE contractors from the Office of Scientific and Technical Information, P.O. Box 62, Oak Ridge, TN 37831; prices available from (615) 576-8401.

Available to the public from the National Technical Information Service, U.S. Department of Commerce; 5285 Port Royal Road, Springfield, VA 22161. 


\section{DISCLAIMER}

\section{Portions of this document may be illegible in electronic image products. Images are produced from the best available original document.}




\section{Preliminary Report on Monosodium Titanate Adsorption Kinetics}

M. G. Bronilkowski, 773-65A

D. T. Hobbs, 773-A

W. R. Wilmarth, 773-42A

Publication Date: October 5, 1998

Westinghouse Savannah River Company

Savannah River Technology Center

Aiken, SC 29808

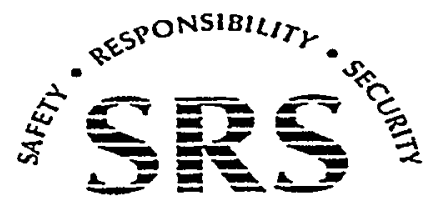

SAVANNAH RIVER SITE 
WSRC-TR-98-00347

page 2 of 16

Revision 0

'Author

Thielad Bronkameki

$10 / 2 / 98$

M. G. Bronikowski, Chemical and Hydrogen Technology Section Date
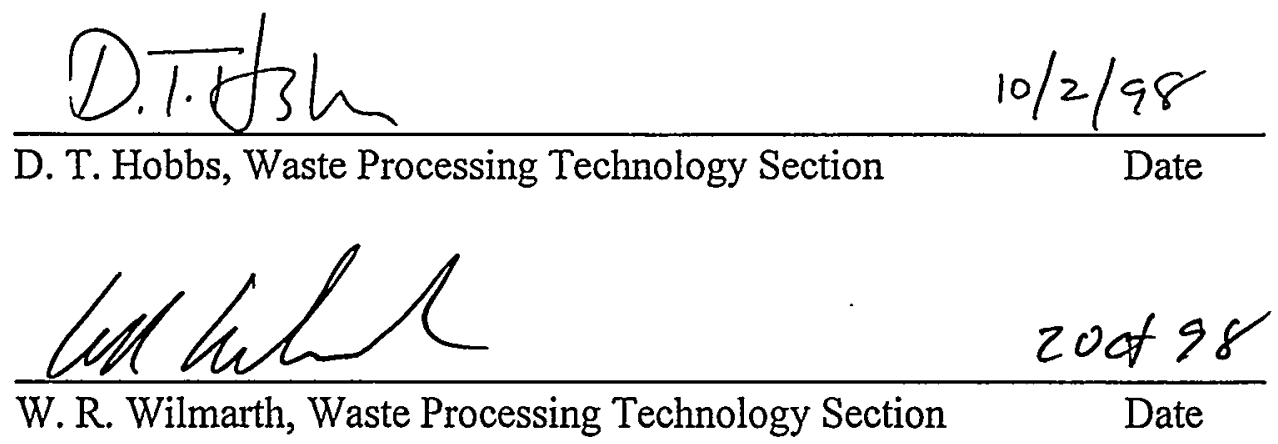

Design Check

\begin{tabular}{cc} 
Darrel 19 . Waller & $10 / 2 / 98$ \\
\hline D. D. Walker, Waste Processing Technology Section & Date
\end{tabular} (per Manual E7, Procedure 2.40)

Approvals

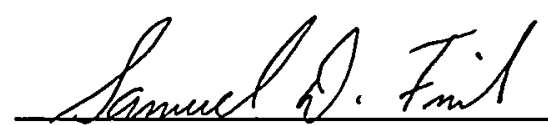

$10-5 \cdot 98$

S. D. Fink, Level 4 Manager, Waste Processing Technology

Date

J. R. Fowler, Senior Fellow Scientist, HLWE

$10 / 5 / 98$

6. T. Carter, In-Tank Precipitation Flow Sheet Team Leader $\frac{10 / 5 / 58}{\text { Date }}$
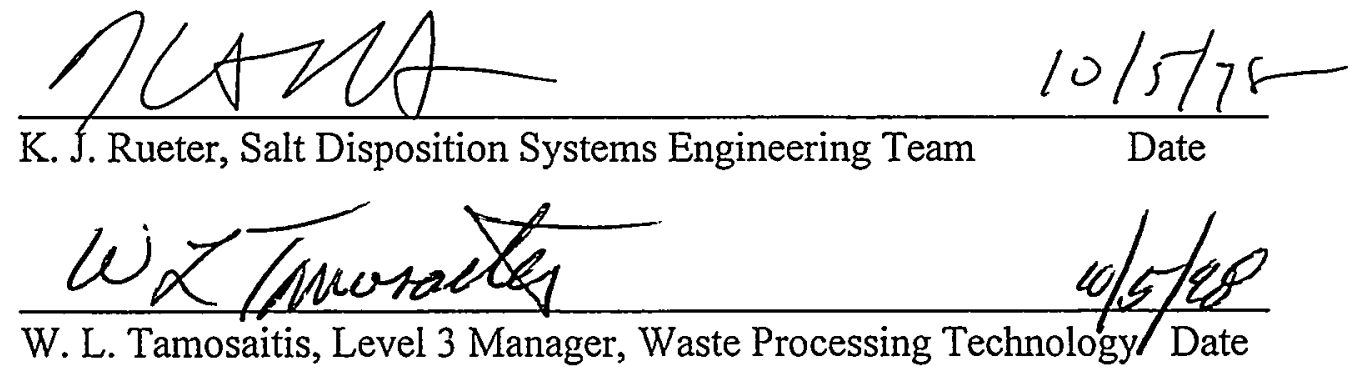


\section{- Summary}

Testing examined the effects of ionic strength $\left(\mathrm{Na}^{+}\right.$concentration), temperature, mixing, sludge solids, and sodium tetraphenylborate (NaTPB) on the extent and rate of strontium, plutonium, neptunium and uranium removal by adsorption onto monosodium titanate (MST). The tests examined performance at different concentrations of strontium, plutonium, neptunium, and uranium in solutions containing different masses of MST. Results of tests conducted at $25^{\circ} \mathrm{C}$ indicate different distribution constants and removal rates for strontium, plutonium and neptunium. Uranium results are unavailable at this time due to delays in obtaining inductively coupled plasma mass spectrometry analyses. The rate data did not fit simple first order or second order kinetic expressions. Strontium adsorbed faster and to a greater extent at high activities (at or near saturation). Plutonium and neptunium generally adsorbed faster at low activities, which suggests a different rate limiting step. In general, extent and rate of adsorption increases with a decrease in the ionic strength or an increase in MST concentration. Mixing and the presence of sludge or NaTPB solids did not affect adsorption extent or rate, except for plutonium in the presence of sludge solids. A later document will report results at the requested higher temperatures of 45 and $65^{\circ} \mathrm{C}$.

\section{Introduction}

The Salt Disposition Systems Engineering Team identified the adsorption kinetics of actinides and strontium onto monosodium titanate (MST) as a technical risk for several of the processing alternatives selected for additional evaluation in Phase III of their effort. The Flow Sheet Team requested that the Savannah River Technology Center (SRTC) examine the adsorption kinetics of MST for several process alternatives [1].

Previously, Hobbs and Walker studied the adsorption of plutonium and uranium onto MST in alkaline solutions [2]. Results of these tests indicate that MST would remove strontium, uranium and plutonium from simulated In-Tank Precipitation (ITP) waste solutions. Hobbs and Fleischman followed with statistically designed testing to examine temperature and chemical composition [3]. Again, the results clearly indicate that MST would sufficiently remove strontium, uranium and plutonium. However, the previous studies did not examine the kinetics of the adsorption process.

This study consisted of a statistically designed set of tests to determine the rate of adsorption of strontium, uranium, neptunium and plutonium as a function of temperature, MST concentration, and concentrations of sodium, strontium, uranium, neptunium and plutonium. Additional tests incorporated into the design assess the effects of mixing as well as the influence from the presence of sludge solids and sodium tetraphenylborate. The Statistical Consulting Section of SRTC assisted in the design of experiments [4].

\section{Experimental}

Preparation of Treated Salt Solution

Personnel prepared 10 liters of a synthetic salt solution from reagent grade chemicals and deionized, distilled (DDI) water yielding the composition provided in Table I.

Undissolved solids were removed by filtering through Whatman \#1 filter paper. - 
Researchers then mixed the filtered solution with 133 grams of MST slurry (20 grams MST, Optima Batch \#33407), stirred the resulting mixture at laboratory temperature for 48 hours before filtering it through a medium porosity sintered glass funnel to remove strontium impurities present in the reagent grade chemicals. They repeated this MST treatment using 15 grams of MST slurry (2.3 grams MST, Optima Batch \#33407), stirring the mixture at ambient laboratory temperature for 72 hours and filtering it through a medium porosity sintered glass funnel. Inductively coupled plasma mass spectrometry (ICP-MS) analysis of the treated solution indicated a strontium concentration of 0.096 $\mathrm{mg} / \mathrm{L}$.

\section{Table I. Composition of Salt Solution}

\begin{tabular}{lc} 
Component & Concentration (M) \\
\cline { 2 - 3 } & 3.47 \\
$\mathrm{NaOH}$ & 1.78 \\
$\mathrm{Na}_{2} \mathrm{SO}$ & 0.694 \\
$\mathrm{NaAl}(\mathrm{OH})_{4}$ & 0.572 \\
$\mathrm{NaNO}_{2}$ & 0.178 \\
$\mathrm{Na}_{2} \mathrm{CO}_{3}$ & 0.0347 \\
Total Na$^{+}$ & 7.46
\end{tabular}

Preparation of High Activity Salt Solutions

Researchers placed $4.8 \mathrm{~L}$ of the treated salt solution in a clean $8 \mathrm{~L}$ polyethylene $(\mathrm{PE})$ carboy. Next, personnel added $5.0 \mathrm{~mL}$ of a nitric acid solution containing $22.13 \mathrm{mg} / \mathrm{mL}$ uranium, $1.12 \mathrm{mg} / \mathrm{mL}$ plutonium and $50.2 \mathrm{mg} / \mathrm{mL}$ neptunium and $0.100 \mathrm{~mL}$ of a solution containing $104 \mathrm{mg} / \mathrm{mL}$ strontium nitrate. The solution stirred at ambient laboratory temperature for 11 days. Next, the test method required pipetting $1.00 \mathrm{~mL}$ of $\mathrm{Sr}-85$ (New England Nuclear, NEZ082, $9.03 \mathrm{mCi} / \mathrm{mg} \mathrm{Sr})$ in hydrochloric acid $(0.28 \mathrm{mCi} / \mathrm{mL})$ into the solution and stirring overnight. The researchers then pipetted $0.50 \mathrm{~mL}$ of Sr-85 in hydrochloric acid $(0.28 \mathrm{mCi} / \mathrm{mL})$ into the solution and stirred it overnight before filtering it through a $0.45 \mu \mathrm{m}$ pore size disposable membrane filter (cellulose nitrate membrane). Persomel then pipetted $1.00 \mathrm{~mL}$ of Sr-85 in hydrochloric acid $(0.28 \mathrm{mCi} / \mathrm{mL})$ into the solution and stirred overnight. The final addition used $1.50 \mathrm{~mL}$ of Sr-85 in hydrochloric acid $(0.28 \mathrm{mCi} / \mathrm{mL})$ followed by 3 days of agitation. Finally, researchers filtered the suspension through a $0.45 \mu \mathrm{m}$ pore size disposable membrane filter (cellulose nitrate membrane) and stored in a clean $8 \mathrm{~L}$ PE carboy labeled as " $7.5 \mathrm{M}$ High".

Researchers prepared a "6.0 M High" stock by adding distilled, deionized water to a sufficient amount of the $7.5 \mathrm{M}$ High solution in a clean PE bottle to produce $2.75 \mathrm{~L}$ of solution with a final sodium concentration of $6.0 \mathrm{M}$. Similarly, researchers prepared 1.5 liters of a " $4.5 \mathrm{M}$ High" stock by dilution.

Preparation of Low Activity Salt Solutions

Researchers placed $4.8 \mathrm{~L}$ of the treated salt solution in a clean $8 \mathrm{~L} \mathrm{PE}$ carboy and added $0.400 \mathrm{~mL}$ of a nitric acid solution containing $22.13 \mathrm{mg} / \mathrm{mL}$ uranium, $1.12 \mathrm{mg} / \mathrm{mL}$ plutonium and $50.2 \mathrm{mg} / \mathrm{mL}$ neptunium. The solution stirred for 11 days at ambient 
"temperature. Personnel then pipetted $1.00 \mathrm{~mL}$ of $\mathrm{Sr}-85$ in hydrochloric acid $(0.28$ $\mathrm{mCi} / \mathrm{mL}$ ) into the solution and stirred it overnight before filtering it through a $0.45 \mu \mathrm{m}$ pore size disposable membrane filter (cellulose nitrate membrane). Researches next pipetted $0.10 \mathrm{~mL}$ of $\mathrm{Sr}-85$ in hydrochloric acid $(0.28 \mathrm{mCi} / \mathrm{mL})$ into the solution and stirred overnight followed by filtration through a $0.45 \mu \mathrm{m}$ pore size disposable membrane filter (cellulose nitrate membrane). They stored the final solution in clean $8 \mathrm{~L} \mathrm{PE}$ carboy labeled as "7.5 M Low". Personnel used distilled, deionized water to dilute the "7.5 M Low" stock solution to yield 2.75 L of "6.0 M Low" and 1.5 L of "4.5 M Low" stock.

\section{Adsorption Tests}

All tests used one of the six salt solutions prepared above, MST manufactured by Optima Chemical Company, Inc. (Batch \#33180), reagent grade sodium tetraphenylborate (Aldrich, Lot \# 01608aQ) and a synthetic Purex sludge prepared by M. J. Barnes (preparation date 12/1/97). Researchers placed $100 \mathrm{~mL}$ of the appropriate salt solution into a capped, high-density $\mathrm{PE}$ bottle and held the solution overnight at temperature (25, $45,65^{\circ} \mathrm{C}$ ). The following day, personnel added the measured quantities of MST, NaTPB and sludge solids to the appropriate test bottle. They then capped the bottles and agitated those bottles in the Lab Line waterbath. Water loss from the Lab Line waterbath during the $65^{\circ} \mathrm{C}$ test required the use of a continuous slow water addition (approximately 2 $\mathrm{mL} / \mathrm{min}$ ) to maintain the liquid level at or above the level in the sample bottles.

Temperature control occurred either by inserting the test bottles into a Fisher Isotemp Model \# 205 waterbath (unagitated) or a Lab Line (Cole-Parmer Catalog \#E-01290-20) waterbath (agitated). Figure 1 presents photographs of test bottles in the two waterbaths. Researchers selected bottle locations at random and changed these for the sets at each temperature.

Personnel recorded waterbath temperatures using thermistor thermometer (Omega ${ }^{\circledR}$ Model \# 5831) with thermistor probes (Omega ${ }^{\circledR}$ Model \#OL-703) inserted into each waterbath. Figures 2-4 give plots of the temperature recordings during each test period. Table II provides calculated average and mean temperatures for each test and waterbath.

Table II. Average and Mean Waterbath Temperatures Temperature $\left({ }^{\circ} \mathrm{C}\right)$

\begin{tabular}{|c|c|c|c|c|}
\hline Target Test & \multicolumn{2}{|c|}{ Isotemp } & \multicolumn{2}{|c|}{ Lab Line } \\
\hline Temperature & Average & Mean & Average & Mean \\
\hline $25^{\circ} \mathrm{C}$ & $\begin{array}{l}25.18 \\
(0.25)\end{array}$ & $\overrightarrow{25.16}$ & $\begin{array}{l}25.48 \\
(0.22)\end{array}$ & 25.43 \\
\hline $45^{\circ} \mathrm{C}$ & $\begin{array}{l}45.41 \\
(0.56)\end{array}$ & 45.37 & $\begin{array}{l}45.38 \\
(0.80)\end{array}$ & 45.66 \\
\hline $65^{\circ} \mathrm{C}$ & $\begin{array}{l}65.06 \\
(0.63)\end{array}$ & 65.19 & $\begin{array}{l}64.12 \\
(1.33)\end{array}$ & 64.36 \\
\hline
\end{tabular}


Figure 1A. Lab Line Orbital Shaker Waterbath

Front View

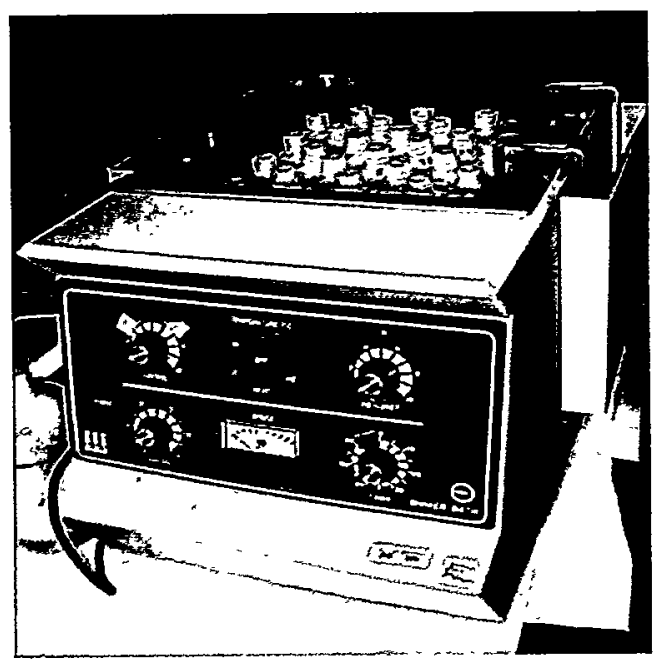

Top View

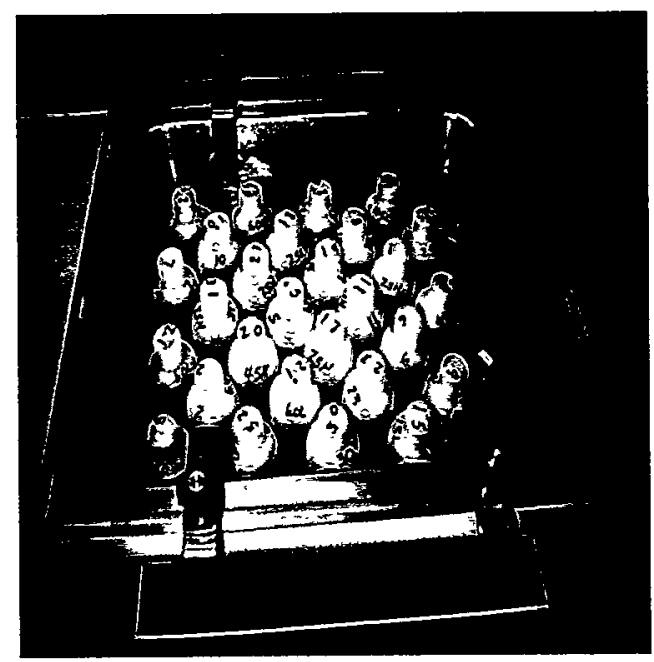

Figure 1B. Isotemp Waterbath

Front View

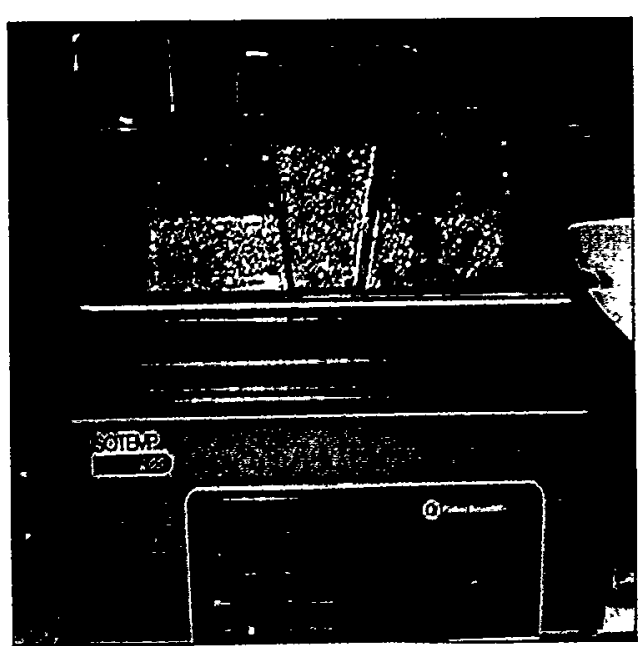

Top View

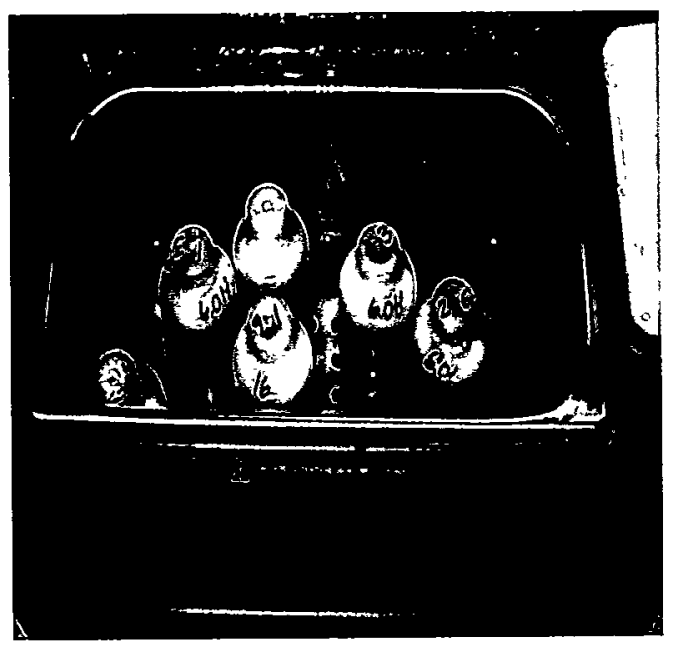


Sampling of each test bottle occurred after approximately 2, 4, 8, 24, 48, and 96 hours in the tests at 45 and $65^{\circ} \mathrm{C}$ tests. The samples for the $25^{\circ} \mathrm{C}$ test occurred at those times as well as at 168 and 240 hours. The sampling method consisted of removing the test bottle from the waterbath, briskly shaking for about 30 seconds to provide a homogeneous suspension, and pulling approximately $5 \mathrm{~mL}$ of the suspension into a disposable plastic syringe. The researcher then inserted a $0.45 \mu \mathrm{m}$ disk filter (nylon membrane) onto the syringe, collected about $4 \mathrm{~mL}$ of filtrate into a clean PE sample bottle and pipeted $3 \mathrm{~mL}$ of the resulting filtrate into a glass vial containing $3 \mathrm{~mL}$ of $5 \mathrm{M}$ nitric acid. All excess filtrate was discarded. Personnel recapped the test bottle and returned it to the waterbath. The total time outside of the waterbath for sampling did not exceed 2 minutes. A white precipitate formed immediately upon mixing of the sample and the nitric acid. Personnel then capped the glass sample vial, gently agitated and allowed to stand at ambient laboratory temperature until all solids dissolved.

The Analytical Development Section of SRTC performed the analyses. Strontium- 85 and neptunium-237 activities determinations occurred by gamma pulse height spectroscopy. Concentration measurements of strontium-88, neptunium-237, uranium-238, plutonium239 and plutonium-240 measurements used ICP-MS (Inductively Coupled Plasma Mass Spectroscopy) analysis. Plutonium-239/240 activity determination relied on alpha spectroscopy after chemical separation from Np-237.

Figure 2. Waterbath Temperature Profiles at $25^{\circ} \mathrm{C}$

\section{Waterbath Temperatures}

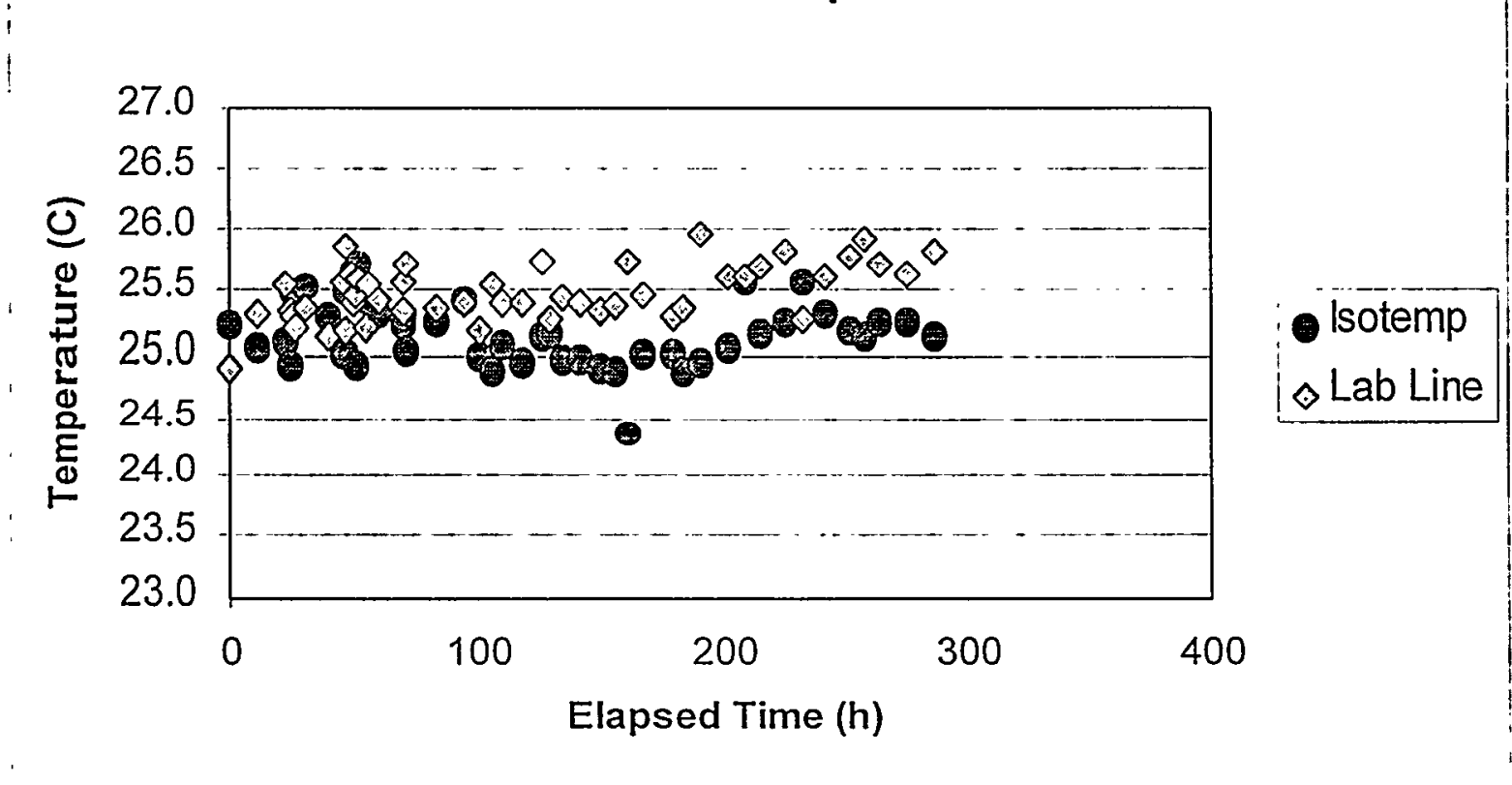


Figure 3. Waterbath Temperature Profiles at $65^{\circ} \mathrm{C}$

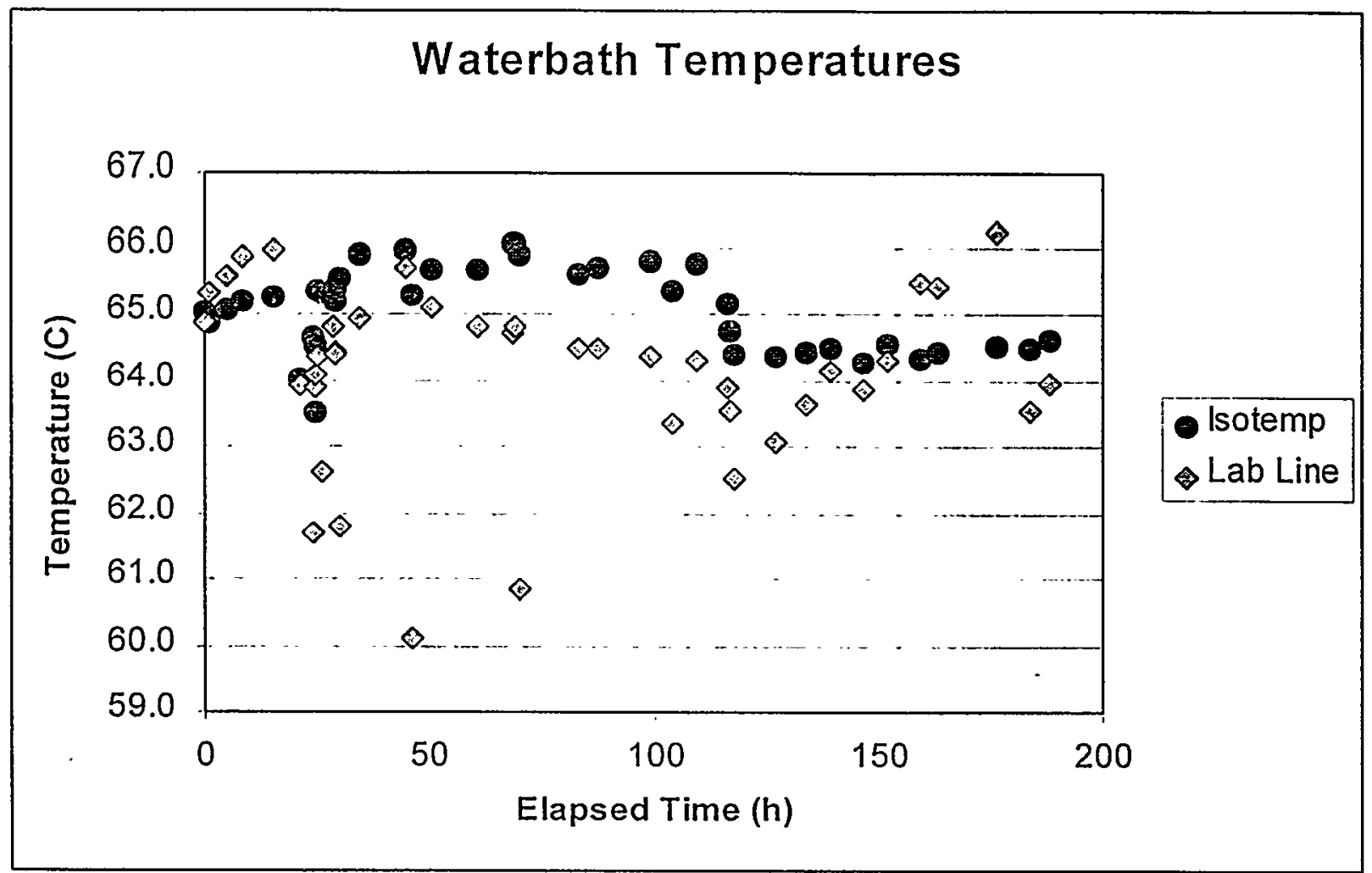

Figure 4. Waterbath Temperature Profiles at $45^{\circ} \mathrm{C}$

\section{Waterbath Temperatures}

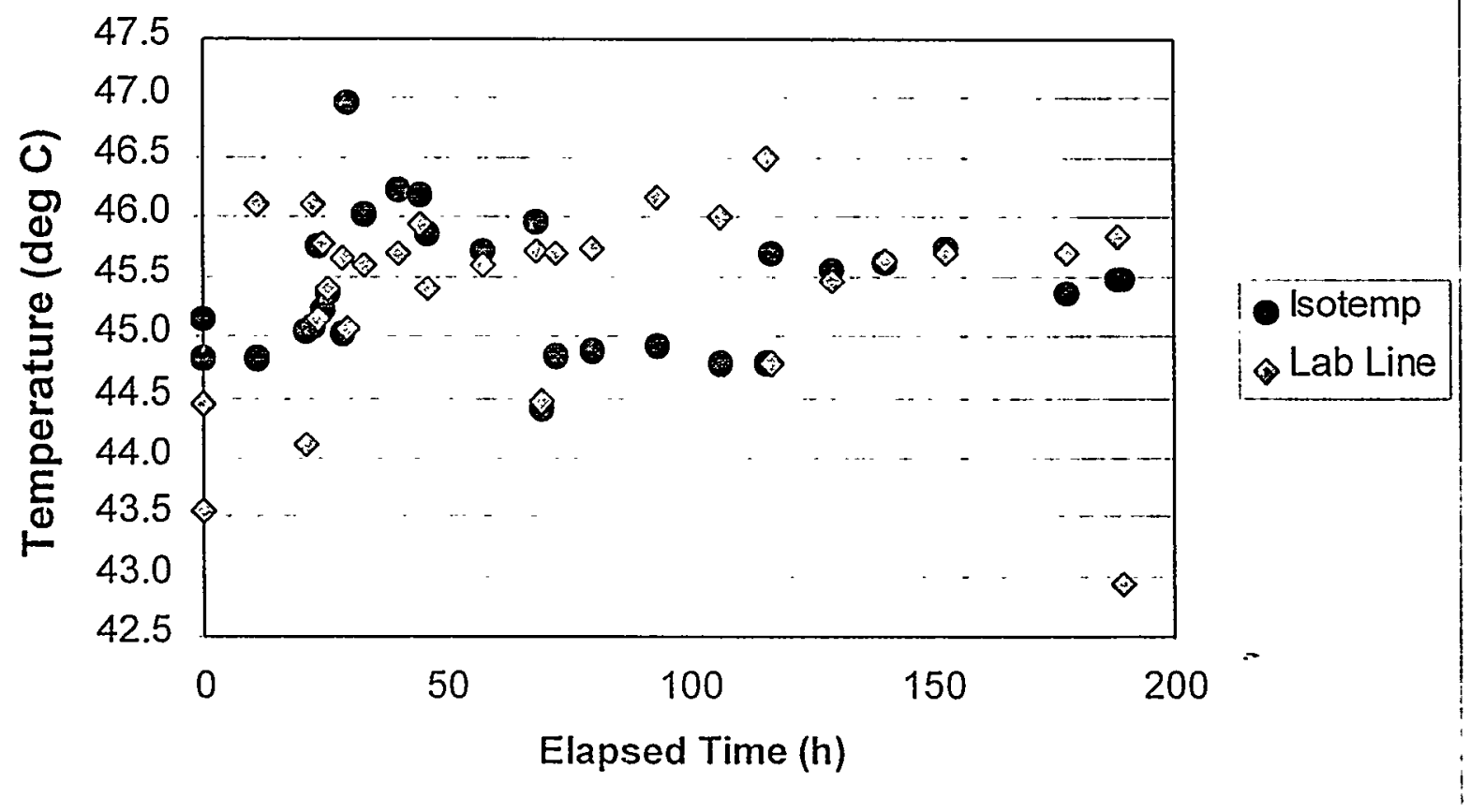




\section{Results and Discussion}

The statistically designed set of tests included the following parameters: temperature, sodium ion concentration, MST concentration, initial concentrations (of strontium, neptunium, uranium and plutonium), mixing, and the presence of sodium tetraphenylborate and sludge solids. Table III provides a list of the targeted range of values for each parameter.

\section{Table III. Targeted Parameter Values}

Parameter
Temperature
Sodium Concentration
MST Concentration'
Mixing

Strontium

Neptunium

Uranium

Plutonium

Sodium Tetraphenylborate

Sludge Solids
Targeted Experimental Range

$\begin{array}{lll}\frac{\text { Low }}{25^{\circ} \mathrm{C}} & \frac{\text { Mid }}{45^{\circ} \mathrm{C}} & \frac{\text { High }}{65^{\circ} \mathrm{C}} \\ 4.5 \mathrm{M} & 6.0 \mathrm{M} & 7.5 \mathrm{M} \\ 0.2 \mathrm{~g} / \mathrm{L} & 1.1 \mathrm{~g} / \mathrm{L} & 2.0 \mathrm{~g} / \mathrm{L} \\ \text { no } & & \text { yes } \\ 0.1 \mathrm{mg} / \mathrm{L} & & 1.0 \mathrm{mg} / \mathrm{L} \\ 4.0 \mathrm{mg} / \mathrm{L} & & 40 \mathrm{mg} / \mathrm{L} \\ 1.0 \mathrm{mg} / \mathrm{L} & & 10 \mathrm{mg} / \mathrm{L} \\ 0.1 \mathrm{mg} / \mathrm{L} & & 1.0 \mathrm{mg} / \mathrm{L} \\ 0.0 \mathrm{mg} / \mathrm{L} & & 400 \mathrm{mg} / \mathrm{L} \\ 0.0 \mathrm{mg} / \mathrm{L} & & 400 \mathrm{mg} / \mathrm{L}\end{array}$

' a MST concentration of $0.0 \mathrm{~g} / \mathrm{L}$ also included as a baseline to estimate adsorption of the radionuclides onto testing equipment.

Table IV provides an outline of the statistical experimental design. The table differs from that originally developed by T. B. Edwards of the SCS to reflect a lower temperature [4]. Due to constraints on the number of bottles that can fit in the agitated waterbath, researcher did not replicate the tests with sludge and NaTPB solids.

Plots of solution activities versus time exhibited the expected exponential decrease in activity with increasing time. None of the test data fit first order or second order kinetic expressions. Therefore, we use as the primary measure for reaction rate the time to reach equilibrium or the time at which a sharp decrease in the slope of the activity-concentration curve occurred. Figure 5 presents a typical plot of activity (e.g., $\mathrm{Sr}-85$ in disintegrations per minute per milliliter (dpm/mL)) or concentration (e.g., Pu-239 in $\mu \mathrm{g} / \mathrm{L}$ ) versus time for a test (test conditions: $6.0 \mathrm{M} \mathrm{Na}^{+}$, low activity solution, $1.1 \mathrm{~g} / \mathrm{L} \mathrm{MST}$, mixed, $25^{\circ} \mathrm{C}$, no sludge and no NaTPB). After eight hours, the rate of decrease in Sr-85 activity significantly slowed indicating the approach of the system to equilibrium with respect to strontium. 
- Table IV. Statistical Design Test Outline

\begin{tabular}{|c|c|c|c|c|c|c|c|c|c|c|c|c|c|}
\hline \multirow{2}{*}{$\begin{array}{l}\text { Experimental } \\
\text { Notes }\end{array}$} & \multicolumn{12}{|c|}{ Actinide (Pu, U, and $\mathrm{Np})$ and Sr Loading } & \multirow[b]{4}{*}{$\operatorname{Rep}$} \\
\hline & \multicolumn{6}{|c|}{ Low } & \multicolumn{6}{|c|}{ High } & \\
\hline & Temp & MST & $\mathrm{Nat}$ & & & & Temp & MST & $\mathrm{Nat}$ & & & & \\
\hline & $\left({ }^{\circ} \mathrm{C}\right)$ & $\mathrm{g} / \mathrm{L}$ & $\mathbf{M}$ & Mixing & TPB & Sludge & $\left({ }^{\circ} \mathrm{C}\right)$ & $\mathrm{g} / \mathrm{L}$ & $\mathbf{M}$ & Mixing & TPB & Sludge & \\
\hline Baseline & 25 & 0 & 6 & Yes & No & No & 25 & 0 & 6 & Yes & No & Nol & Yes \\
\hline \multirow[t]{3}{*}{ Special } & 25 & 1.1 & 6 & Yes & Yes & No & 25 & 1.1 & 6 & Yes & Yes & No & No \\
\hline & 25 & 1.1 & 6 & Yes & No & Yes & 25 & 1.1 & 6 & Yes & No & Yes & No \\
\hline & 25 & 1.1 & 6 & No & No & No & 25 & I.I & 6 & No & No & No & Yes \\
\hline \multirow[t]{5}{*}{ Designed } & 25 & 1.1 & 6 & Yes & No & No & 25 & 1.1 & 6 & Yes & No & No & Yes \\
\hline & 25 & 0.2 & 4.5 & Yes & No & No & 25 & 0.2 & 4.5 & Yes & No & No & Yes \\
\hline & 25 & 0.2 & 7.5 & Yes & No & No & 25 & 0.2 & 7.5 & Yes & No & No & Yes \\
\hline & 25 & 1 & 4.5 & Yes & No & No & 25 & 1 & 4.5 & Yes & No & No & Yes \\
\hline & 25 & 1 & 7.5 & Yes & No & No & 25 & 1 & 7.5 & Yes & No & No & Yes \\
\hline Baseline & 70 & 0 & 6 & $\overline{\text { Yes }}$ & No & No & 70 & 0 & 6 & Yes & No & No & Yes \\
\hline \multirow[t]{3}{*}{ Special } & 70 & 1.1 & 6 & Yes & Yes & No & 70 & 1.1 & 6 & Yes & Yes & No & No \\
\hline & 70 & 1.1 & 6 & Yes & No & Yes & 70 & 1.1 & 6 & Yes & No & Yes & No \\
\hline & 70 & 1.1 & 6 & No & No & Nol & 70 & 1.1 & 6 & No & No & No & Yes \\
\hline \multirow[t]{5}{*}{ Designed } & 70 & 1.1 & 6 & Yes & No & No & 70 & 1.1 & 6 & Yes & No & No & Yes \\
\hline & 70 & 0.2 & 4.5 & Yes & No & No & 70 & 0.2 & 4.5 & Yes & No & No & Yes \\
\hline & 70 & 0.2 & 7.5 & Yes & No & No & 70 & 0.2 & 7.5 & Yes & No & No & Yes \\
\hline & 70 & 2 & 4.5 & Yes & No & No & 70 & 2 & 4.5 & Yes & No & No & Yes \\
\hline & 70 & 2 & 7.5 & Yes & No & No & 70 & 2 & 7.5 & - Yes & No & No & Yes \\
\hline Baseline & 45 & 0 & 6 & Yes & No & No & 45 & 0 & 6 & Yes & No & No & Yes \\
\hline \multirow[t]{3}{*}{ Special } & 45 & 1.1 & 6 & Yes & Yes & No & 45 & 1.1 & 6 & Yes & Yes & No & No \\
\hline & 45 & 1.1 & 6 & Yes & No & Yes & 45 & 1.1 & 6 & Yes & No & Yes & No \\
\hline & 45 & 1.1 & 6 & No & No & $\mathrm{No}$ & 45 & 1.1 & 6 & No & No & No & Yes \\
\hline \multirow[t]{10}{*}{ Designed } & 45 & 0.2 & 6 & Yes & No & No & 45 & 0.2 & 6 & Yes & No & No & No \\
\hline & 45 & 2 & 6 & Yes & No & No & 45 & 2 & 6 & Yes & No & No & No \\
\hline & 45 & 1.1 & 4.5 & Yes & No & No & 45 & 1.1 & 4.5 & Yes & No & No & No \\
\hline & 45 & 1.1 & 7.5 & Yes & No & No & 45 & 1.1 & 7.5 & Yes & No & No & No \\
\hline & 45 & 1.1 & 6 & Yes & No & No & 45 & 1.1 & 6 & Yes & No & No & No \\
\hline & 45 & 1.1 & 6 & Yes & No & $\mathrm{No}$ & 45 & 1.1 & 6 & Yes & No & No & No \\
\hline & 45 & I.I & 6 & Yes & No & No & 45 & 1.1 & 6 & Yes & No & No & No \\
\hline & 45 & 1.1 & 6 & Yes & No & No & 45 & 1.1 & 6 & Yes & No & No & No \\
\hline & 45 & 1.1 & 6 & Yes & No & No & 45 & 1.1 & 6 & Yes & No & No & No \\
\hline & 45 & 1.1 & 6 & Yes & No & No & 45 & 1.1 & 6 & Yes & No & No & No \\
\hline
\end{tabular}


Figure 5. Strontium-85 Activity Versus Time - Test Bottle 221

Test conditions: $6.0 \mathrm{M} \mathrm{Na}^{+}$, low activity solution, $1.1 \mathrm{~g} / \mathrm{L} \mathrm{MST}$, mixed, $25^{\circ} \mathrm{C}$, no sludge and no $\mathrm{NaTPB}$ -Time of sharp rate decrease occurs at 8 hours)--

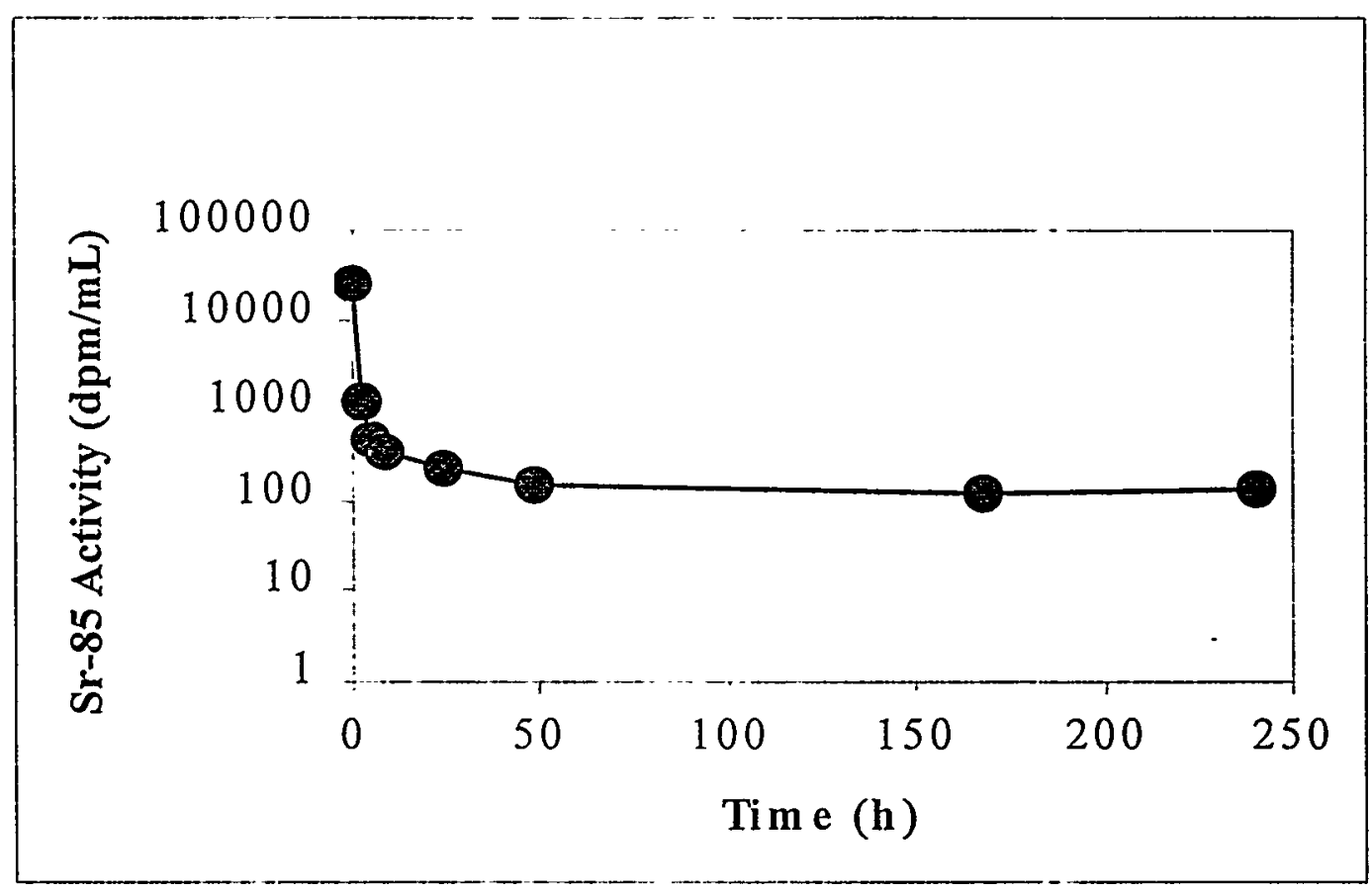

Strontium Removal

Table $V$ presents a summary of the average equilibrium distribution constant, $K_{d}$, and the reaction times for strontium at each of the test conditions. The measured $\mathrm{K}_{d} \mathrm{~S}$ for strontium agree well with previously measured the value $\left(1.2 \times 10^{5}\right)$ from $5.0 \mathrm{M} \mathrm{Na}^{+}$salt solutions saturated in strontium, uranium and plutonium [2].

The adsorption data did not fit first or second order kinetic expressions. For high activity solutions, saturated or nearly saturated in strontium and actinides, equilibrium occurred in 24 hours or less. Low activity solutions, well below saturation, exhibited longer times to reach equilibrium. These results correlate with the lower chemical potentials in the low activity solutions, which decrease adsorption rates.

Increasing ionic strength (i.e., $\mathrm{Na}^{+}$concentration) decreased equilibrium constants and adsorption rates. One expects this behavior since strontium removal depends on surface ion-exchange of sodium ion in the MST matrix. Increasing MST concentration increased adsorption rates, as expected, as more adsorption sites become available with higher MST concentrations. Mixing and the presence of sludge and NaTPB exhibited no discernible effect on the adsorption characteristics of strontium (see Table VIII). 
- Table V. $\mathrm{K}_{\mathrm{d}}$ and Times for Strontium Removal at $25^{\circ} \mathrm{C}$

\begin{tabular}{|c|c|c|c|c|}
\hline $\mathrm{Na}+](\mathrm{M})$ & {$[\mathrm{MST}](\mathrm{g} / \mathrm{L})$} & Activity & $\underline{K}_{d}(\mathrm{~mL} / \mathrm{g})^{a}$ & $\underline{\operatorname{Time}}(\mathrm{h})^{\mathrm{b}}$ \\
\hline 4.5 & 0.2 & low & $1.9 \times 10^{5}$ & 48 \\
\hline 4.5 & 0.2 & high & $1.9 \times 10^{6}$ & 8 \\
\hline 7.5 & 0.2 & low & $3.8 \times 10^{4}$ & 168 \\
\hline 7.5 & 0.2 & high & $3.8 \times 10^{4}$ & 24 \\
\hline 6.0 & 1.1 & low & $2.2 \times 10^{5}$ & 168 \\
\hline 6.0 & 1.1 & high & $1.2 \times 10^{5}$ & 2 \\
\hline 4.5 & 2.0 & low & $7.8 \times 10^{5}$ & 4 \\
\hline 4.5 & 2.0 & high & $8.5 \times 10^{5}$ & 2 \\
\hline 7.5 & 2.0 & low & $4.9 \times 10^{4}$ & 168 \\
\hline 7.5 & 2.0 & high & $3.4 \times 10^{5}$ & 2 \\
\hline
\end{tabular}

a average of duplicate tests. $K_{d}=(D F-1) / C$ where $D F$ is the decontamination factor and equals the initial activity or concentration divided by the activity concentration at time $\mathrm{x}$ with $\mathrm{C}$ as the concentration of MST in units of $\mathrm{g} / \mathrm{mL}$.

${ }^{b}$ the lesser of the time to reach equilibrium or the time at which a sharp decrease in the slope of the activity/concentration curve occurred.

\section{Plutonium Removal}

Table VI presents a summary of the average distribution constant, $\mathrm{K}_{\mathrm{d}}$, and the reaction times for plutonium at each of the test conditions. The measured $\mathrm{K}_{d} \mathrm{~S}$ for plutonium agree well with previously measured value $\left(4.8 \times 10^{4}\right)$ from $5.0 \mathrm{M} \mathrm{Na}^{+}$salt solution saturated in strontium, uranium and plutonium [2].

The adsorption data did not fit first or second order kinetic expressions. For high activity solutions, saturated or nearly saturated in plutonium and actinides, equilibrium occurred in 36 hours or less. Low activity solutions, well below saturation, exhibited shorter times to reach equilibrium (16 hours or less). Equilibrium constants typically proved much higher for the high activity solutions than the low activity solutions.

Decreasing ionic strength (i.e., $\mathrm{Na}^{+}$concentration) and increasing MST concentration generally increased adsorption rates. For high activity solutions, only at high MST concentration $(2.0 \mathrm{~g} / \mathrm{L})$ did the equilibrium constant change (decrease) with increased ionic strength. Increases in MST concentration at constant ionic strength produced no discernible change in equilibrium constants.

Mixing and the presence of NaTPB exhibited no discernible effect on the adsorption characteristics of plutonium (see Table VIII). The presence of sludge solids exhibited no effect with high activity solutions, but did exhibit an effect on low activity solutions. For low activity solutions, the effective equilibrium constant and adsorption rate increased 
upon addition of sludge solids. The higher effective equilibrium constant likely reflects plutonium adsorbing onto the sludge solids in addition to MST solids.

Table VI. $\mathrm{K}_{\mathrm{d}}$ and Times for PIutonium Removal at $25^{\circ} \mathrm{C}$

\begin{tabular}{|c|c|c|c|c|}
\hline $\mathrm{Na}+](\mathrm{M})$ & {$[\mathrm{MST}](\mathrm{g} / \mathrm{L})$} & Activity & $\underline{K}_{d}(\mathrm{~mL} / \mathrm{g})^{\mathrm{a}}$ & $\underline{\text { Time }(h)^{b}}$ \\
\hline 4.5 & 0.2 & low & $3.1 \times 10^{4}$ & 2 \\
\hline 4.5 & 0.2 & high & $4.1 \times 10^{5}$ & 16 \\
\hline 7.5 & 0.2 & low & $2.0 \times 10^{3}$ & 48 \\
\hline 7.5 & 0.2 & high & $5.0 \times 10^{5}$ & 36 \\
\hline 6.0 & 1.1 & low & $9.4 \times 10^{3}$ & 8 \\
\hline 6.0 & 1.1 & high & $1.5 \times 10^{4}$ & 16 \\
\hline 4.5 & 2.0 & low & $4.7 \times 10^{3}$ & 2 \\
\hline 4.5 & 2.0 & high & $4.1 \times 10^{4}$ & 2 \\
\hline 7.5 & 2.0 & low & $1.6 \times 10^{3}$ & 36. \\
\hline 7.5 & 2.0 & high & $5.0 \times 10^{4}$ & 16 \\
\hline
\end{tabular}

\section{Neptunium Removal}

Table VII presents a summary of the average distribution constant, $\mathrm{K}_{\mathrm{d}}$, and the reaction times for neptunium at each of the test conditions. Equilibrium constants prove much lower for neptunium than plutonium primarily due to the much higher mass concentration of neptunium (1-20 mg/L) compared to plutonium $(0.01-0.1 \mathrm{mg} / \mathrm{L})$.

The adsorption data did not fit simple first or second order kinetic expressions. For high activity solutions, saturated or nearly saturated in plutonium and actinides, equilibrium occurred in 168 hours or less. Low activity solutions, well below saturation, exhibited shorter times to reach equilibrium (48 hours or less). Equilibrium constants typically proved much higher for the low activity solutions than the high activity solutions. With high activity solutions, MST loads to saturation as the solutions contained limited quantity.

Decreasing ionic strength (i.e., $\mathrm{Na}^{+}$concentration) concentration generally increased adsorption rates with no effect on equilibrium constants. Increasing MST concentration exhibited no discernible effect on equilibrium constants or adsorption rates. Mixing and the presence of sludge and NaTPB exhibited no discernible effect on the adsorption characteristics of neptunium (see Table VIII). 
Table VII. $\mathrm{K}_{\mathrm{d}}$ and Times for Neptunium Removal at $25^{\circ} \mathrm{C}$

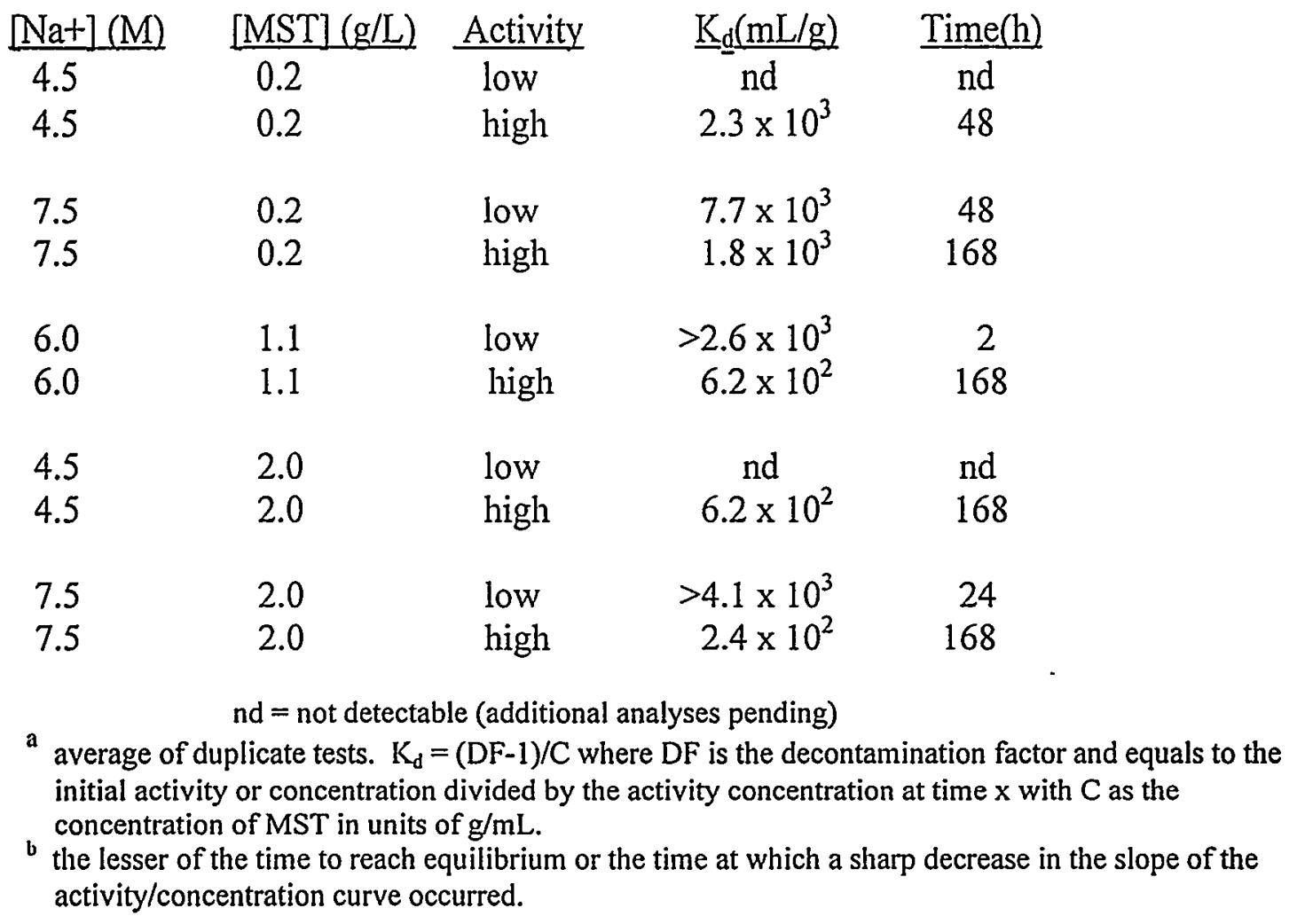

Table VIII. Effects of Mixing, Sludge and NaTPB on $\mathrm{K}_{\mathrm{d}}$ and Times for Strontium, Plutonium and Neptunium

\begin{tabular}{|c|c|c|c|c|}
\hline \multirow[b]{2}{*}{ Conditions } & \multirow{2}{*}{$\begin{array}{l}\text { Solution } \\
\text { Activity }\end{array}$} & \multicolumn{3}{|c|}{$\mathrm{K}_{\mathrm{d}}, \mathrm{ml} / \mathrm{g}$ (AdsorptionTime, $\left.\mathrm{h}\right)^{\mathrm{a}}$} \\
\hline & & Strontium & Plutonium & Neptunium \\
\hline Mixed, w/o ${ }^{b}$ & low & $2.2 \times 10^{5}(168)$ & $1.5 \times 10^{4}(16)$ & $>2.6 \times 10^{3}(2)$ \\
\hline Mixed, w/o & high & $1.2 \times 10^{6}(2)$ & $9.4 \times 10^{4}(8)$ & $>6.2 \times 10^{2}(168)$ \\
\hline Unmixed, w/o & low & $1.7 \times 10^{5}(168)$ & $9.3 \times 10^{3}(8)$ & $>2.6 \times 10^{3}(2)$ \\
\hline Unmixed, w/o ${ }^{b}$ & high & $8.4 \times 10^{5}(2)$ & $9.4 \times 10^{4}(4)$ & $5.3 \times 10^{3}(168)$ \\
\hline Mixed, w/ sludge $\mathrm{c}^{\mathrm{c}}$ & low & $3.0 \times 10^{5}(8)$ & $1.6 \times 10^{5}(2)$ & $>2.6 \times 10^{3}(2)$ \\
\hline Mixed, w/ sludge ${ }^{c}$ & high & $5.5 \times 10^{5}(4)$ & $9.4 \times 10^{4}(4)$ & $9.9 \times 10^{2}(168)$ \\
\hline Mixed, w/ NaTPB ${ }^{d}$ & low & $9.5 \times 10^{4}(168)$ & $1.6 \times 10^{4}(24)$ & $>4.8 \times 10^{3}(4)$ \\
\hline Mixed, w NaTPB & high & $1.4 \times 10^{6}(4)$ & $9.4 \times 10^{4}(8)$ & $4.1 \times 10^{2}(168)$ \\
\hline
\end{tabular}




\section{Quality Assurance}

This work used the following task plan.

W. R. Wilmarth, D. T. Hobbs and M. G. Bronikowski, "Phase III Test Plan for MST Adsorption Kinetics," WSRC-RP-98-00736, revision 0, August 10, 1998.

This document provides the first deliverable for the work requested in the authorizing task request,

P. L. Rutland, "MST Alpha Removal and Hg Removal for Salt Team Phase 3 Evaluation," HLE-TAR-98062, revision 0, July 15, 1998.

Notebook WSRC-NB-98-00220 (D. T. Hobbs) contains the experimental data from the studies.

\section{Acknowledgements}

The authors thank the many people who helped bring this work to completion. M.S. Blume and H. L. Thacker conducted much of the experimental work involved in the adsorption experiments. E. A. Kyser and K. J. Kalbaugh supplied actinide materials. J. L. Siler assisted with equipment photography. The staff of the Analytical Developmental Section of the SRTC performed the many chemical and radiochemical analyses.

\section{References}

1. P. L. Rutland, "MST Alpha Removal and Hg Removal for Salt Team Phase 3 Evaluation," HLE-TAR-98062, Rev. 0, July 15, 1998.

2. D. T. Hobbs and D. D. Walker, "Plutonium and Uranium Adsorption on Monosodium Titanate (U)," WSRC-RP-92-93, August 13, 1992.

3. D. T. Hobbs and S. D. Fleischman, "Fissile Solubility and Monosodium Titanate Loading Tests (U)," WSRC-RP-92-1273, February 12, 1993.

4. T. B. Edwards, "A Statistically Designed Experimental Plan Supporting LWP's Study of MST Adsorption Kinetics (U)," SRT-SCS-98-034, July 23, 1998. 
$\mathrm{CC}$ :

G. E. Abell, 704-3N

B. N. Attaway, 773-A

J. L. Barnes, 704-3N

M. J. Barnes, 773-A

S. B. Beck, 704-3N

N. E. Bibler, 773-A

J. D. Carison, 703-H

J. T. Carter, 704-25S

G. L. Cauthen, 241-119H

W. C. Clark, 704-56H

C. L. Crawford, 773-41A

Dr. E. Cussler, 704-3N

N. R. Davis, 703-H

R. A. Dimenna, 773-42A

L. O. Dworjanyn, 779-2A

R. E. Eibling, 704-T

H. H. Elder, 704-S

S. D. Fink, 773-A

F. Fondeur, 773-62A

J. R. Fowler, 704-3N

M. W. Geeting, 773-24A

J. C. Griffin, 773-A .

T. Hang, 773-42A

D. T. Hobbs, 773-A

E. W. Holtzscheiter, 773-A

P. I. Hudson, $704-3 \mathrm{~N}$

R. A. Jacobs, 704-3N

M. D. Johnson, 703-H

M. T. Keefer, 241-153H

P. S. Kirkland, 703-46A

E. J. Kosiancic, 704-3N

L. F. Landon, 704-T

B. L. Lewis, 703-H
T. J. Lex, 703-H

P. E. Lowe, 773-41A

D. J. McCabe, 773-42A

J. W. McCollough, 703-H

M. S. Miller, 704-56H

T. M. Monahon, 703-H

J. P. Morin, 703-H

E. T. Murphy, 704-3N

C. A. Nash, 773-42A

L. M. Nelson, 773-43A

L. M. Papouchado, 773-A

P. K. Paul, 773-42A

R. A. Peterson, 773-A

S. F. Piccolo, 704-3N

M. R. Poirier, 676-T

M. J. Polochko, 773-A

K. J. Rueter, 706-S

P. L. Rutland, 704-196N

R. H. Spires, 703-H

W. E. Stevens, 773-A

P. C. Suggs, $704-3 \mathrm{~N}$

R. F. Swingle, 773-A

W. L. Tamosaitis, 773-A

G. A. Taylor, 704-196N

W. B. VanPelt, 676-1T

D. D. Walker, 773-A

Dr. J. Watson, 704-3N

W. R. Wilmarth, 773-42A

G. T. Wright, 773-A

J. E. Young, 773-A

TIM, 703-43A

WPTS Files, 773-A, c/o S. Poston, 773-A

ITP files, c/o A. G. Wiest, $241-119 \mathrm{H}$ 